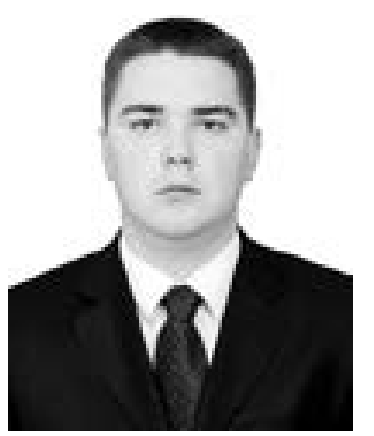

\title{
КРИМІНОЛОГІЧНИЙ АНАЛІЗ РІВНЯ РОЗКРИТТЯ ЗАГАЛЬНОКРИМІНАЛЬНИХ НАСИЛЬНИЦЬКИХ ЗАОЧИНІВ В УКРАЇНІ
}

ІГНАТОВ Олександр Миколайович - кандидат юридичних наук, старший науковий співробітник, доцент кафедри кримінального права та кримінології Одеського державного університету внутрішніх справ

УДК 343.9

Статья посвящена криминологическому анализу уровня раскрьттия общеуголовньхх насильственных преступлений и соответствующих изменений в структуре данного вида преступности, осуществленному на основании анализа статистических данньх за последние двенадиать лет (в том числе в условиях действия нового уголовно-процессуального законодательства).

Ключові слова: кримінологічний аналіз, рівень, розкриття, насильство, злочин.

Життя людини, іï здоров'я і свобода є неперевершеними i нескороминущими соціальними цінностями. Тому цілісний аналіз кримінального насильства, його тенденцій і закономірностей має виняткове кримінологічне, соціальне і навіть політичне значення [1, с. 407]. Прагнення ж України інтегруватися в європейське і світове співтовариство диктує необхідність застосування світових стандартів в області обліку й аналізу скоєних у країні злочинів [2, с. 17]. у свою чергу зміни показників щодо стану насильницької злочинності свідчать про ефективність чи неефективність кримінологічної політики держави та вдалий чи невдалий розподіл сил та застосування засобів протидії кримінальному насильству й злочинності в цілому та, відповідно, дозволяють приймати подальші управлінські рішення.

Проблеми протидії насильницькій злочинності у своїх в працях досліджувало багато вітчизняних та зарубіжних науковців: Ю.М. Антонян, О.М. Бандурка,
В.О. Глушков, В.В. Голіна, Б.М. Головкін, Л.М. Давиденко, А.І. Долгова, I.М. Даньшин, О.М. Джужа, В.П. Емельянов, А.Ф. Зелінський, А.П. Закалюк, Я.Ю. Кондратьєв, О.М. Костенко, В.М. Кудрявцев, Н.Ф. Кузнєцова, І.П. Аановенко, О.М. Аитвак, О.М. Аитвинов, В.В. Сташис, В.Я. Тацій, B.М. Трубников, I.К. Туркевич, В.I. Шакун та ін. Незважаючи на наявні чіслені дослідження насильницької злочинності, на сьогодні, попри виключну суспільну небезпеку кримінального насильства, у науковому обігу знаходяться недостатні дані щодо стану насильнцикьої злочинності в Україні як в цілому, так і відносно найбільш поширених та небезпечних видів насильницьких злочинів зокрема.

Одним із основних i найважливіших елементів кримінологічної характеристики стану злочинності є іï рівень. При цьому значний інтерес викликає рівень розкриття злочинів. Саме аналіз рівня розкриття окремих видів злочинів дає уявлення про ефективність протидї злочинності 3 боку правоохоронних органів та залежність змін структури злочинності від діяльності останHix.

Метою даної статті $є$ кримінологічний аналіз рівня розкриття загальнокримінальних насильницьких злочинів в Україні. ÏÏ новизна полягає у тому, що на підставі аналізу статистичних даних здійснено критичний аналіз рівня розкриття загальнокримінальних насильницьких злочинів в Україні за останні дванадцять років (у тому числі в 
умовах дії нового кримінально-процесуального законодавства) та відповідних змін у структурі даного виду злочинності.

Аналіз статистичних даних МВС України за 2002-2012 рр. [3] показав, що частка загальнокримінальної насильницької злочинності у структурі всієї зареєстрованої злочинності складає $15,3 \%$. Усього в Україні за даний період було вчинено 782524 злочинів даного виду. Ранжирування загальнокримінальних насильницьких злочинів за рівнем розкриття свідчить про наступну їх градацію.

Найвищий рівень розкриття спостерігається за ст. 123 КК України (умисне тяжке тілесне ушкодження, заподіяне у стані сильного душевного хвилювання) і має показник у $126 \%$ (тут і надалі відсоток розкриття перевищує 100\% зареєстрованих злочинів, оскільки враховуються усі злочини, що знаходилися у провадженні протягом аналізованого періоду). Друге місце займає ст. 116 КК України (умисне вбивство, вчинене в стані сильного душевного хвилювання) - $124 \%$. Третє місце за рівнем розкриття у ст. 118 КК України (умисне вбивство при перевищенні меж необхідної оборони або у разі перевищення заходів, необхідних для затримання злочинця) - $117 \%$. На четвертому місці ст. 124 КК України (умисне заподіяння тяж- ких тілесних ушкоджень у разі перевищення меж необхідної оборони або у разі перевищення заходів, необхідних для затримання злочинця) - 109\%, а на п'ятому - ст. 115 КК України (умисне вбивство) - 101\%.

Наступні декілька злочинів мають рівень розкриття близький до 100\%, а саме - ст. 152 КК України (згвалтування) - 97\%, ст. 129 КК України (погроза вбивством) та ст. 189 КК України (вимагання) - по 94\%, ст. 187 (розбій), 153 КК України (насильницьке задоволення статевої пристрасті неприродним способом), ст. 121 КК України (умисне тяжке тілесне ушкодження), ст. 126 КК України (побої і мордування), ст. 117 КК України (умисне вбивство матір'ю своєї новонародженої дитини) - по 93\%, ст. 127 КК України (катування) - 92\%, ст. 125 КК України (умисне легке тілесне ушкодження) - 91\%.

Наступні злочини мають рівень розкриття у межах від 70,0 до 80,0\%. До таких злочинів відносяться - ст. 146 КК України (незаконне позбавлення волі або викрадення людини) - 83\%, ст. 296 КК України (хуліганство) - 74\%, ст. 122 КК України (умисне середньої тяжкості тілесне ушкодження) - 72\%.

Останні два злочини, що складають структуру загально кримінальної насильницької злочинності, мають досить низький рівень розкриття, а саме: - злочини, перед-

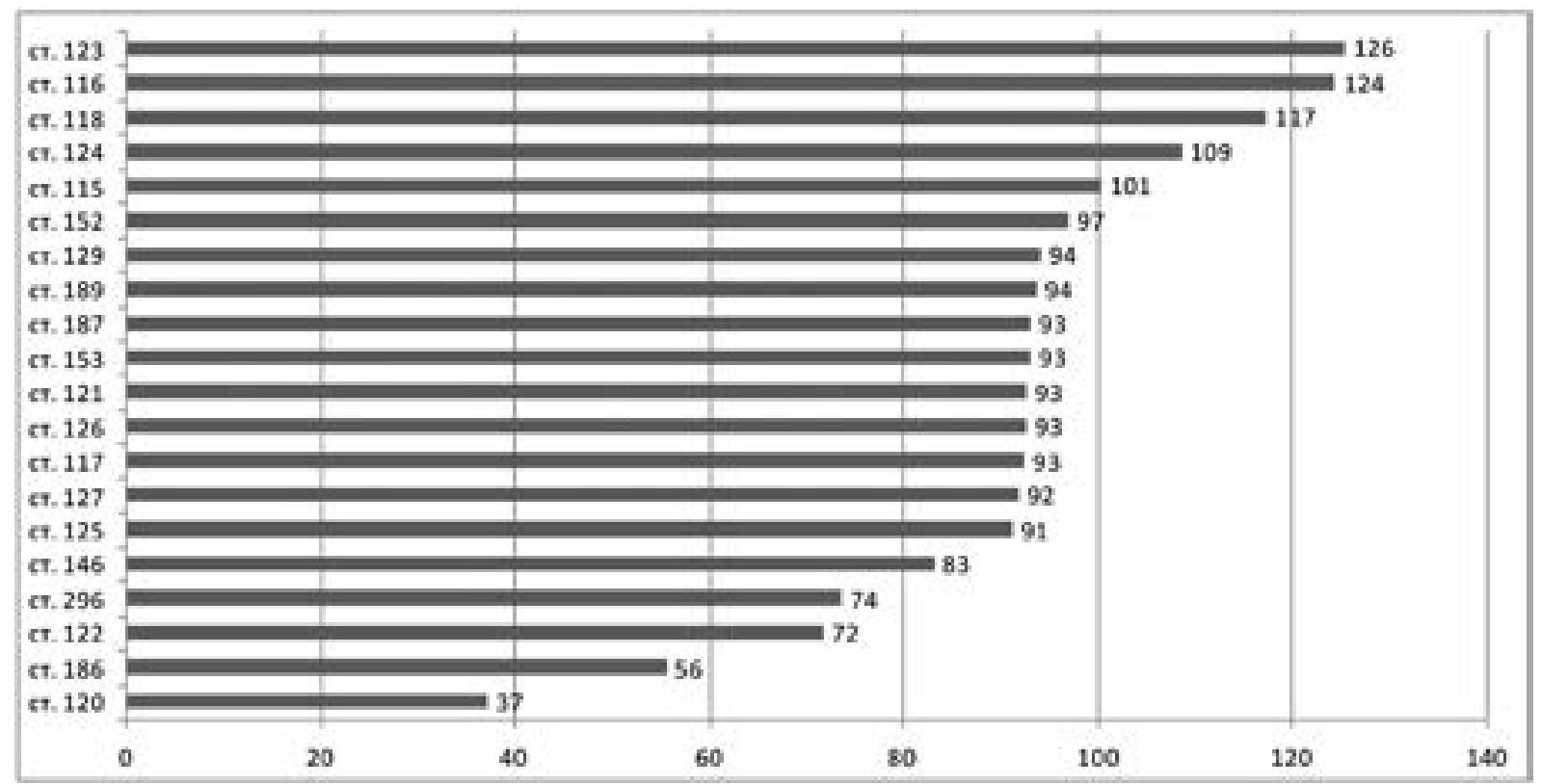

Рис. 1. Ранжирування загальнокримінальних насильницьких злочинів в Україні за 2002-2012 рр. за рівнем розкриття. 
бачені ст. 186 КК України (грабіж) - 56\%, ст. 120 КК України (доведення до самогубства) $-37 \%$ (рис. 1$)$.

Як можна наочно бачити, п'ять з усіх видів загальнокримінальних насильницьких злочинів мають $100 \%$ рівень розкриття. Ще десять видів мають рівень розкриття понад $90 \%$.

Необхідно звернути увагу, що на перші чотири позиції за рівнем розкриття виходять так звані привілейовані склади загальнокримінальних насильницьких злочинів (ст. 123, ст. 116, ст. 118, ст. 124 КК України), які за абсолютною кількістю та коефіцієнтом злочинної інтенсивності у розрахунку на 100000 населення займають у структурі загальнокримінальної насильницької злочинності практично найнижчі місця $(20,17$, 15 та 13-те місце відповідно).

У свою чергу, злочини, які складають першу п'ятірку у рейтингу за абсолютною кількістю та коефіцієнтом злочинної інтенсивності у розрахунку на 100000 населення: ст. 186 (грабіж), ст. 296 (хуліганство), ст. 122 (умисне середньої тяжкості тілесне ушкодження), ст. 187 (розбій), ст. 121 КК України (умисне тяжке тілесне ушкодження), за рівнем розкриття займають 19, 17, 18, 9 та 11-те місце у структурі загальнокримінальної насильницької злочинності відповідно.

Таким чином, можна бачити, що рівень розкриття загальнокримінальних насиль- ницьких злочинів близький до абсолюту, забезпечується переважно за рахунок очевидних злочинів невеликої та середньої тяжкості. При цьому ці злочини лідирують по темпу зниження їх рівня протягом 20022012 рр. У свою чергу, грабіж (ст. 186 КК України), якій складає 43,44\% усієї структури злочинності даного виду має рівень розкриття лише $56 \%$.

y цілому можна констатувати наявну сьогодні наступну тенденцію - при зростанні рівня того чи іншого загальнокримінального насильницького злочину відбувається практично пропорційне зниження рівня його розкриття та навпаки. При чому така пропорційність корелює зі ступенем тяжкості злочину.

Це свідчить про те, що сьогодні значну роль у діяльності правоохоронних органів щодо протидії злочинності грає об’єктивно їх обмежений (у першу чергу, через недостатне фінансування, застарілу модель функціонування та організаційні недоліки, при чому відповідний стан правоохоронних органів, зокрема ОВС лише поступово погіршується) потенціал («пропускна спроможність») щодо виявлення та розслідування злочинів [4, с. 71-124]. При цьому, очевидне збереження установки на максимальне розкриття резонансних тяжких та особливо тяжких злочинів. Очевидно, що така ситу-

Таблиця 1

Абсолютна кількість зареєстрованих злочинів та рівень їх розкриття в Україні за 2002-2012 рр.

\begin{tabular}{|l|l|l|l|l|l|}
\hline Роки & $\begin{array}{c}\text { Зареєстрова- } \\
\text { но злочинів }\end{array}$ & $\begin{array}{c}\text { Динаміка (у \%) } \\
\text { до поперед. року }\end{array}$ & $\begin{array}{c}\text { Розкрито (розслі- } \\
\text { дувано) }\end{array}$ & $\begin{array}{c}\text { Відсоток } \\
\text { розкриття }\end{array}$ & $\begin{array}{c}\text { Не розкри- } \\
\text { то }\end{array}$ \\
\hline 2002 & 450661 & $-10,5$ & 403824 & 83.3 & 80774 \\
\hline 2003 & 556351 & $+23,5$ & 385827 & 69,3 & 182085 \\
\hline 2004 & 520105 & $-6,5$ & 372137 & 65,7 & 194536 \\
\hline 2005 & 485725 & $-6,6$ & 335309 & 64,5 & 184800 \\
\hline 2006 & 420900 & $-13,3$ & 298306 & 66,6 & 149921 \\
\hline 2007 & 401293 & $-4,7$ & 303971 & 69,5 & 133221 \\
\hline 2008 & 384424 & $-4,2$ & 295918 & 71,4 & 118814 \\
\hline 2009 & 434678 & $+13,1$ & 298650 & 64,3 & 165576 \\
\hline 2010 & 500902 & $+15,2$ & 324483 & 57,2 & 218949 \\
\hline 2011 & 515833 & $+3,0$ & 319589 & 55,3 & 237224 \\
\hline $2012 *$ & 443665 & $-6,6$ & 283407 & 56,2 & 205506 \\
\hline
\end{tabular}

*Дані за 2012 рік до набрання чинності новим КПК України. 
ація не може не відобразитися й на практиці реєстрації злочинів, оскільки стан таких злочинів традиційно служить загальним, універсальним індикатором криміногенної обстановки в державі та ефективності діяльності правоохоронних органів.

Статистичні дані свідчать, що у цілому криміногенна ситуація в Україні в 20022012 рр. характеризується стабільною тенденцією до зменшення кількості зареєстрованих злочинів у порівнянні з аналогічним попереднім періодом, хоча динаміка змін рівня злочинності безпосередньо за цей період досить мінлива, в окремі роки відбувалося зростання рівня злочинності (табл. 1).

Як випливає 3 наведених даних, з одного боку можна бачити зниження останніми роками рівня розкриття злочинів, що підтверджує викладену вище тезу про стан правоохоронних органів, з іншого боку, при відповідному в цілому світовій практиці середньому рівню рівня розкриття злочинів в Україні у 60\%, викликає деякі запитання стабільний рівень розкриття загальнокримінальних насильницьких злочинів, у першу чергу, тяжких та особливо тяжких, понад 90\%.

У світлі змін кримінально-процесуального законодавства [5] та пов'язаних з цим змін обліково-реєстраційної практики правоохоронних органів на окрему увагу заслуговує аналіз криміногенної ситуації у державі за 8 місяців 2013 р. [6]. Так, рівень заяв та повідомлень про злочини, правопорушення та інші події, які надійшли до МВС України за вказаний період, у порівнянні з минулим роком фактично не змінився. За 8

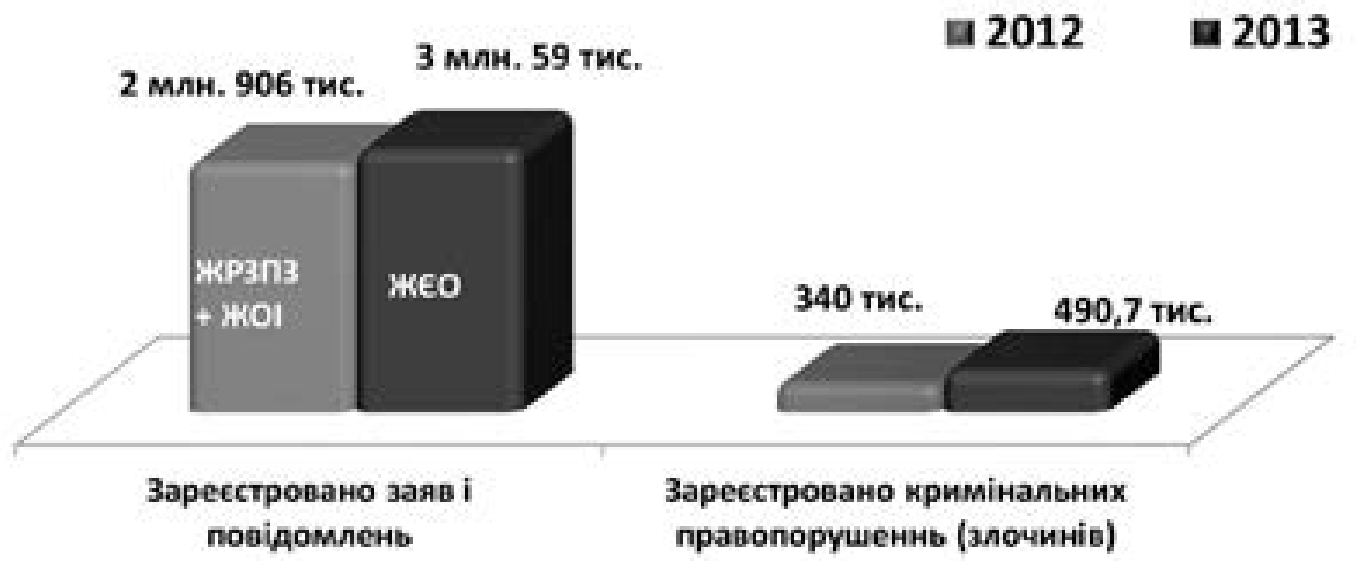

Рис. 2. Рівень заяв та повідомлень про злочини, правопорушення та інші події, які надійшли до МВС України за 8 місяців 2012 р. та 8 місяців 2013 р. місяців 2012 р. в Україні було зареєстровано (ЖРЗПЗ (журнал реєстрації заяв та повідомлень про злочини) та ЖОІ (журнал обліку інформації) 2 млн. 906 тис. заяв. Кримінальні справи було порушено по 340 тис. злочинів, що складає $12 \%$ від загальної кількості зареєстрованих заяв. За 8 місяців 2013 р. в Україні було зареєстровано (ЖЕО - журнал єдиного обліку 3 млн. 59 тис. заяв. Зареєстровано (внесено) до ЕРДР 1 млн. 61 тис. заяв, що складає $26 \%$ від загальної кількості зареєстрованих заяв.

На перший погляд, зазначені показники відображають зростання числа осіб, які вважають, що по відношенню до них було вчинено кримінальне правопорушення та звернулися з цього приводу до правоохоронних органів. Однак суттєво рівень враженості населення країни злочинністю не змінився. У свою чергу, якщо в минулому році лише за кожною восьмою заявою порушувались кримінальні справи, то на сьогодні - досудове розслідування розпочинається за кожною третьою заявою. Таким чином, по суті можна казати про зростання рівня правоохоронного обслуговування громадян щодо розгляду та прийняття процесуальних рішень за їх заявами та повідомленнями.

При цьому, за вказаний період у Сдиному реєстрі досудових розслідувань (ЕРДР) 3 1 млн. 61 тис. заяв зареєстровано 490,7 тис. кримінальних правопорушень, що на 44 відсотки більше від кількості облікованих злочинів за аналогічний період минулого року (340 тис.). Зростання цього показника обумовлюється змінами у Кримінально-

\section{$2012 \square 2013$}


му процесуальному законодавстві, якими скасовано інститут дослідчої перевірки та таку стадію процесу, як відмова в порушенні кримінальної справи. Відтепер всі заяви, які мають хоча 6 формальні ознаки кримінального правопорушення, реєструються в ЕРДР та за ними проводиться досудове розслідування (рис. 2).

Отже, протягом аналізованого періоду було закрито понад 50\% (570,5 тис.) кримінальних проваджень у зв'язку з відсутністю складу або події злочину. Відповідне досудове розслідування продовжується за кожною шостою заявою та повідомленням із числа облікованих до Єдиного обліку у поточному році.
Таким чином, можна зробити висновок, що в умовах дії принципово нового кримінально-процесуального законодавства, відповідно, принципово нових умовах обліку та реєстрації злочинів (кримінальних правопорушень), рівень реєстрації злочинності (або його штучне регулювання, обумовлене «пропускною спроможністю»?) залишається практично незмінним.

При цьому, у порівнянні $з$ аналогічним періодом попереднього року, можна спостерігати зменшення масиву тяжких та особливо тяжких загальнокримінальних насильницьких злочинів (кримінальних правопорушень), зокрема: умисних убивств - на 20\% (з 1667 до 1338); тяжких тілесних

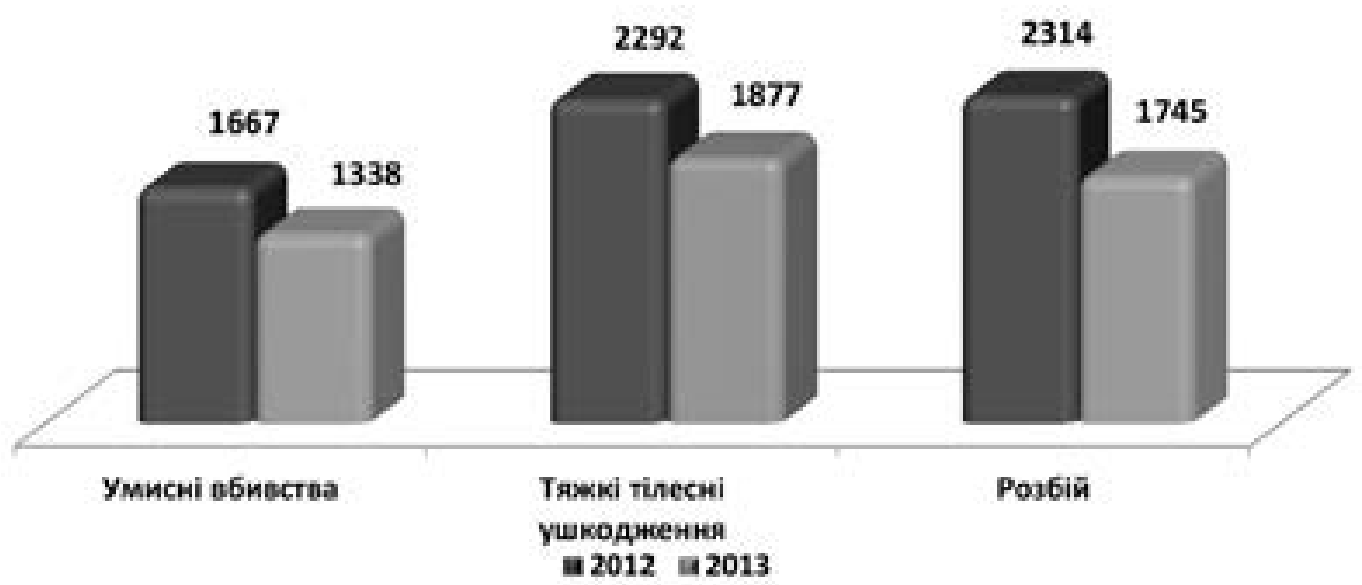

Рис. 3. Рівень реєстрації умисних вбивств (ст.115 КК України); тяжких тілесних ушкоджень (ст. 121 КК України); розбоїв (ст. 187 КК України) в Україні за 8 місяців 2012 р. та 8 місяців 2013 р.

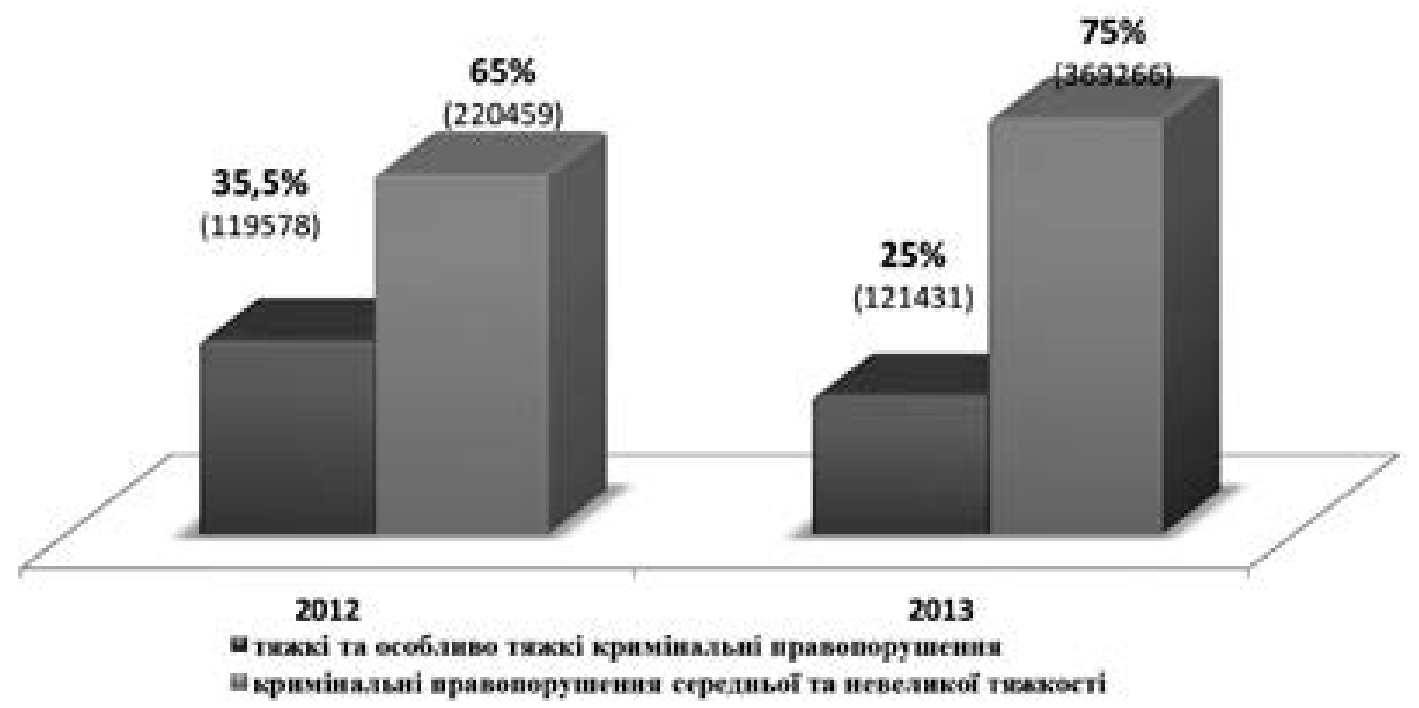

Рис. 4. Розподіл зареєстрованої злочинності в Україні за 8 місяців 2012 р. та 8 місяців 2013 р. за ступенем тяжкості. 
ушкоджень - на $18 \%$ (з 2292 до 1877), у тому числі зі смертельними наслідками - на $11 \%$ (з 533 до 472); розбійних нападів - на 25\% (3 2314 до 1745) (рис. 3).

Отже ситуація з загальнокримінальною насильницькою злочинністю в цілому відбиває основні зміни в структурі загальної зареєстрованої злочинності, що полягають у зниженні (що розпочалося у середині 2000-х р.) частки тяжких та особливо тяжких кримінальних правопорушень 335 до 25 відсотків (рис. 4).

Безумовно, на таке положення справ впливає те, що значний масив злочинів середньої та невеликої тяжкості виходить 3 розряду латентних та відображається в статистичній звітності. У той же час, це дає правоохоронним органам можливість маніпулювати «вибірковою» реєстрацією злочинів (правопорушень) на рівні реєстрації заяв та закриття кримінальних проваджень.

Щодо рівня розкриття загальнокримінальних насильницьких злочинів, то в 2013 р. також зберігається зазначена вище тенденція. Так, наприклад, у 2013 р. у порівнянні $з$ минулим роком спостерігається зростання рівня розкриття таких злочинів, як: умисне убивство - $389 \%$ до 92\%; тяжких тілесних ушкоджень - з 90\% до 92\%, у тому числі зі смертельними наслідками - $391 \%$ до $94 \%$ (рис. 5).

Усього до Единого реєстру досудових розслідувань за період з 20.11.2012 р. по 30.09 .2013 р. за окремими видами загальнокримінальних насильницьких злочинів (кримінальних правопорушень) внесено відомості (з урахуванням кримінальних правопорушень, у яких провадження закрито за реабілітуючими підставами) [7] щодо: ст.ст. 115-118 КК України - 128705 правопорушень; ст.ст. 120-127 КК України - 234078 правопорушень; ст. 129 КК України - 29717 правопорушень; ст. 146 КК України - 2584 правопорушень; ст. 152 КК України - 1500 правопорушень; ст. 153 КК України - 456 правопорушень; ст. 186 КК України - 29142 правопорушень; ст. 187 КК України - 3775 правопорушень; ст. 189 КК України; ст. 296 КК України - 37901 правопорушень. Рівень їх розкриття відповідає зазначеним вище тенденціям, що мали місце у попередній період.

На відсутність сьогодні суттєвих змін у практиці реєстрації та розслідування злочинів в Україні, в тому числі загальнокримінальних насильницьких злочинів, свідчить судова практика. Так, за даними статистики Державної судової адміністрації України [8] у 2012 р. кількість кримінальних справ, що знаходились у провадженні судів першої та апеляційної інстанцій, за загальнокримінальними насильницькими злочинами,

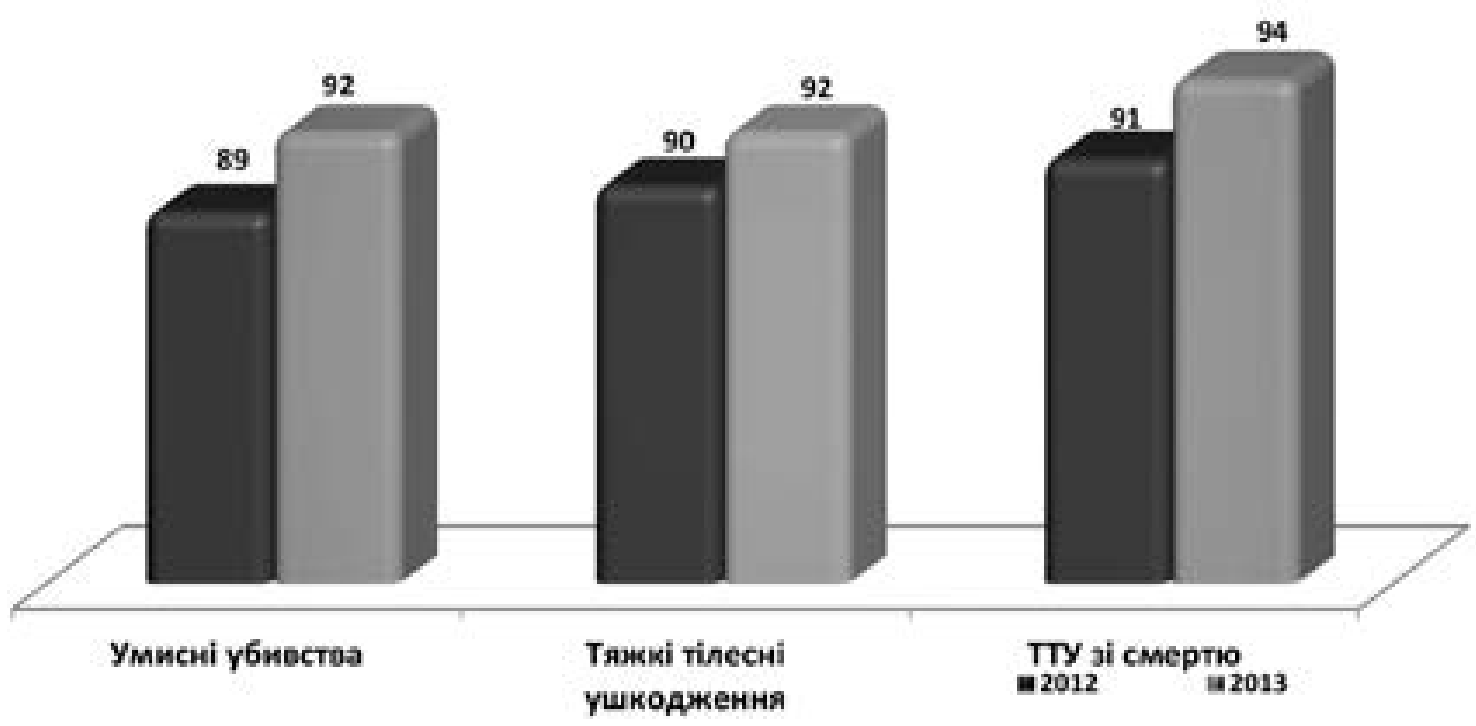

Рис. 5. Рівень розкриття умисних вбивств (ст.115 КК України); тяжких тілесних ушкоджень (ст. 121 КК України); розбоїв (ст. 187 КК України) в Україні за 8 місяців 2012 р. та 8 місяців 2013 р. 
передбаченими статтями 115, 121, 122, 146, 152, 186, 187, 296 КК України, порівняно 3 попередніми звітними періодами (2010, 2011 роки) зменшилась (табл. 2).
- ту іiі частину, яка ними офіційно реєструється. Остання, в свою чергу, набагато перевищує ту їі частину, що розкривається, а кількість розкритих діянь - кількість злочи-

Таблиця 2

Рух справ кримінального судочинства у судах першої інстанції за загальнокримінальними насильницькими злочинами, передбаченими статтями 115, 121, 122, 146, 152, 186, 187, 296 КК України у 2012 р. - I півріччі 2013 р.

\begin{tabular}{|c|c|c|c|c|c|c|c|c|c|c|}
\hline \multirow{2}{*}{\multicolumn{2}{|c|}{$\begin{array}{c}\text { Найменування показ- } \\
\text { ників }\end{array}$}} & \multicolumn{8}{|c|}{ За злочинами, передбаченими статтями КК } & \multirow{2}{*}{$\sum$} \\
\hline & & 115 & 121 & 122 & 146 & 152 & 186 & 187 & 296 & \\
\hline \multicolumn{11}{|c|}{ Рух справ у 2012 році } \\
\hline $\begin{array}{l}\text { Надійг } \\
\text { них сп }\end{array}$ & $\begin{array}{l}\text { шло криміналь- } \\
\text { грав }\end{array}$ & 3031 & 3768 & 4878 & 91 & 482 & 9255 & 2936 & 4548 & 35319 \\
\hline $\begin{array}{l}\text { Знахо } \\
\text { дженн }\end{array}$ & $\begin{array}{l}\text { дилось у прова- } \\
\text { i справ }\end{array}$ & 4480 & 5400 & 6089 & 128 & 743 & $\begin{array}{c}11 \\
988\end{array}$ & 4497 & 5954 & 47819 \\
\hline $\begin{array}{l}\text { Закінч } \\
\text { ням сп }\end{array}$ & $\begin{array}{l}\text { чено проваджен- } \\
\text { прав }\end{array}$ & 3026 & 3987 & 4971 & 83 & 504 & 9674 & 3125 & 4773 & 36537 \\
\hline У т.ч. & $\begin{array}{l}3 \text { постановлен- } \\
\text { ням вироку }\end{array}$ & 2305 & 3505 & 4156 & 62 & 417 & 8867 & 2690 & 3610 & 30457 \\
\hline \multicolumn{11}{|c|}{ Рух справ у I півріччі 2013 року } \\
\hline \multicolumn{2}{|c|}{$\begin{array}{l}\text { Надійшло криміналь- } \\
\text { них справ }\end{array}$} & 1269 & 1560 & 1677 & 26 & 175 & 3665 & 1136 & 1658 & 13898 \\
\hline \multicolumn{2}{|c|}{$\begin{array}{l}\text { Знаходилось у прова- } \\
\text { дженні справ }\end{array}$} & 2684 & 2987 & 2786 & 68 & 408 & 5957 & 2485 & 2832 & 25100 \\
\hline \multicolumn{2}{|c|}{$\begin{array}{l}\text { Закінчено проваджен- } \\
\text { ням справ }\end{array}$} & 1430 & 1704 & 1806 & 33 & 223 & 3860 & 1332 & 1689 & 14785 \\
\hline У т.ч. & $\begin{array}{l}3 \text { постановлен- } \\
\text { ням вироку }\end{array}$ & 1131 & 1516 & 1294 & 24 & 181 & 3519 & 1152 & 1280 & 12189 \\
\hline
\end{tabular}

Як це видно з таблиці 2, у 2013 р. у порівнянні з попереднім роком кількість справ, закінчених провадженням 3 постановленням вироку, в цілому знижується, що відбиває загальну тенденцію зниження кількості реєстрованих і загальнокримінальних насильницьких злочинів (кримінальних правопорушень), що розкриваються у країні.

Одним 3 показників стану злочинності $\epsilon$ рівень осіб, що засуджуються за вчинення злочинів. Що стосується безпосередньо загальнокримінальної насильницької злочинності, то вона відповідає загальній закономірності пропорційного зниження показників залежно від рівня аналізу злочинності. Суть цієї закономірності полягає в тому, що, як слушно зазначає В. В. Лунеєв, повсюди фактична злочинність в багато разів перевищує злочинність, про яку відомо органам правосуддя, а відома їм злочинність нів, за вчинення яких винні притягуються до кримінальної відповідальності. Ще менше діянь стає предметом судового розгляду. I ще менше - за скоєння яких суди виносять обвинувальні вироки з призначенням покарання [1, с. 125].

Щодо порівняння кількості осіб, засуджених за вчинення загальнокримінальних насильницьких злочинів (кримінальних правопорушень) до та після змін у кримінально-процесуальному законодавстві, то, $з$ огляду на наявну інформацію за перше півріччя 2013 р., можна констатувати, що суттєвих змін даного показника по підсумках поточного року очікувати не слід (табл. 3).

Однак, слід звернути увагу на деякі показники, зокрема на збільшення в декілька разів кількості осіб, засуджених за вчинення таких злочинів, як умисне легке тілесне ушкодження та побої і мордування. 3біль- 
Кількість осіб, засуджених судами першої інстанції за загальнокримінальні насильницькі злочини, в Україні у 2012 р. - I півріччі 2013 р.

\begin{tabular}{|c|c|c|c|}
\hline \multirow[b]{2}{*}{ Види загально-кримінальних насильницьких злочинів } & \multirow{2}{*}{$\begin{array}{l}\text { Статті } \\
\text { КК }\end{array}$} & \multicolumn{2}{|c|}{$\begin{array}{l}\text { Кількість засудже- } \\
\text { них осіб }\end{array}$} \\
\hline & & 2012 & $\begin{array}{l}\text { I півріч- } \\
\text { чя } 2013 \\
\text { року }\end{array}$ \\
\hline Умисне вбивство & 115 & 1395 & 629 \\
\hline $\begin{array}{l}\text { Умисне вбивство, вчинене в стані сильного душевного } \\
\text { хвилювання }\end{array}$ & 116 & 26 & 9 \\
\hline Умисне вбивство матір'ю своєї новонародженої дитини & 117 & 7 & 4 \\
\hline $\begin{array}{l}\text { Умисне вбивство при перевищенні меж необхідної оборо- } \\
\text { ни або у разі перевищення заходів, необхідних для затри- } \\
\text { мання злочинця }\end{array}$ & 118 & 54 & 31 \\
\hline Доведення до самогубства & 120 & 3 & 2 \\
\hline Умисне тяжке тілесне ушкодження & 121 & 2793 & 1271 \\
\hline Умисне середньої тяжкості тілесне ушкодження & 122 & 3733 & 1128 \\
\hline $\begin{array}{l}\text { Умисне тяжке тілесне ушкодження, заподіяне у стані } \\
\text { сильного душевного хвилювання }\end{array}$ & 123 & 11 & 4 \\
\hline $\begin{array}{l}\text { Умисне заподіяння тяжких тілесних ушкоджень у разі } \\
\text { перевищення меж необхідної оборони або у разі переви- } \\
\text { щення заходів, необхідних для затримання злочинця }\end{array}$ & 124 & 160 & 57 \\
\hline Умисне легке тілесне ушкодження & 125 & 1146 & 2462 \\
\hline Побої і мордування & 126 & 52 & 163 \\
\hline Катування & 127 & 63 & 18 \\
\hline Погроза вбивством & 129 & 480 & 133 \\
\hline Незаконне позбавлення волі або викрадення людини & 146 & 81 & 31 \\
\hline Згвалтування & 152 & 315 & 124 \\
\hline $\begin{array}{l}\text { Насильницьке задоволення статевої пристрасті неприрод- } \\
\text { ним способом }\end{array}$ & 153 & 116 & 69 \\
\hline Грабіж & 186 & 9643 & 3522 \\
\hline Розбій & 187 & 2421 & 1103 \\
\hline Хуліганство & 296 & 4085 & 1457 \\
\hline
\end{tabular}

шення кількості осіб, засуджених за дані злочини, на наш погляд, обумовлено покращенням якості досудового розслідування ОВС кримінальних правопорушень, пов'язаних iз впровадження нового Кримінального процесуального кодексу України. Зокрема 3 впровадженням та ефективним застосуванням інституту угод про примирення. Так, лише з 20.11.2012 р. по 30.09.2013 р. до суду скеровано понад 8 тис. обвинувальних актів з угодами про примирення [7].
Таким чином, кримінологічний аналіз рівня розкриття загальнокримінальних насильницьких злочинів в Україні за 2002-2012 pр. дозволив виявити наступне. В умовах дії принципово нового кримінально-процесуального законодавства, відповідно, принципово нових умовах обліку та реєстрації злочинів (кримінальних правопорушень), рівень реєстрації злочинності залишається практично незмінним. Рівень розкриття загальнокримінальних насильницьких зло- 
Ігнатов О.М. - Кримінологічний аналіз рівня розкриття...

АНОтАЦІЯ
Стаття присвячена кримінологічному
аналізу рівня розкриття загальнокриміналь-
них насильницьких злочинів та відповіднх
змін у структурі даного виду злочинності, здій-
сненому на підставі аналізу статистичних да-
них за останні дванадиять років (у тому числі
в умовах дї нового кримінально-прочесуального
законодавства).

чинів близький до абсолюту, забезпечується переважно за рахунок очевидних злочинів невеликої та середньої тяжкості (при цьому ці злочини лідирують по темпу зниження їх рівня). Безумовно, на таке положення справ пливає те, що значний масив злочинів середньої та невеликої тяжкості виходить 3 розряду латентних та відображається в статистичній звітності. У той же час, це дає правоохоронним органам можливість маніпулювати «вибірковою» реєстрацією злочинів (правопорушень) на рівні реєстрації заяв та закриття кримінальних проваджень.

У цілому можна констатувати наступну тенденцію - при зростанні рівня того чи іншого загально-кримінального насильницького злочину відбувається практично пропорційне зниження рівня його розкриття та навпаки. При чому така пропорційність корелює зі ступенем тяжкості злочину. Це свідчить про те, що сьогодні значну роль у діяльності правоохоронних органів щодо протидії злочинності відіграє об'єктивно їх обмежений (у першу чергу через недостатне фінансування, застарілу модель функціонування та організаційні недоліки, при чому відповідний стан правоохоронних органів, зокрема ОВС лише поступово погіршується) потенціал («пропускна спроможність») щодо виявлення та розслідування злочинів. При цьому, очевидне збереження установки на максимальне розкриття резонансних тяжких та особливо тяжких злочинів. Очевидно, що така ситуація не може не відобразитися й на практиці реєстрації злочинів, оскільки стан таких злочинів традиційно служить загальним, універсальним індикатором криміногенної обстановки в державі та ефективності діяльності правоохоронних органів.

\section{SUMMARY}

The article is sanctified to the criminology analysis of level of opening the crimes of violence and corresponding changes in the structure of this type of criminality, carried out on the basis of analysis of statistical data for the last twelve years (including in the conditions of action of new criminal legislation).

\section{Література}

1. Аунеев В. В. Преступность XX века: мировые, региональные и российские тенденции / В. В. Аунеев. - 2-е изд., перераб. и доп. - М.: Волтерс Клувер, 2005. - 912 с.

2. Бандурка А. М. Преступность в Украине: причины и противодействие: монография / А. М. Бандурка, $\Lambda$. М. Давыденко. - Х.: Основа, 2003. $-368 \mathrm{c}$.

3. Звіт МВС України про злочинність (форма № 1, затверджено Наказом МВС України від 27.07.2010 р. № 332) за 2002-2012 роки.

4. Игнатов А. Н. Убийство: криминолого-статистического исследование: Монография / А. Н. Игнатов. - Симферополь: КРП «Издательство «Крымучпедгиз», 2012. - 176 с.

5. Кримінальний процесуальний кодекс України від 13.04.2012 р. // Відомості Верховної Ради України. - 2013. - № 9-10, № 11-12, № 13. Ст. 88.

6. Відомості про зареєстровані злочини за період 1960-1990, 2002-2012 роки, аналітична інформація про стан криміногенної ситуації в Україні та злочинності за напрямком роботи підрозділів карного розшуку. Аист МВС України від 02 жовтня 2013 року № 16991/Дв на № 04-20/10-1906 від 20.09.2013.

7. Інформація про стан загально-кримінальної насильницької злочинності в Україні за 2002-2012 роки; про кількість внесених до Єдиного реєстру досудових розслідувань (з 20.11.2012) правоохоронними органами відомостей про кримінальні правопорушення; про якість діяльності правоохоронних органів з розслідування загальнокримінальних насильницьких злочинів. Аист Генеральної прокуратури України 04/2/8-2173-13 від 04.10.2013.

8. Аналіз даних судової статистики щодо розгляду місцевими загальними судами, апеляційними судами областей, міст Києва та Севастополя, Апеляційним судом Автономної Республіки Крим кримінальних справ за злочинами, передбаченими статтями 115, 121, 122, 146, 152, 186, 187, 296 Кримінального кодексу України, за 2010 рік - I півріччя 2013 року. Аналіз стану здійснення судочинства та даних судової статистики щодо розгляду справ і матеріалів ВССУ за 2010-2012 роки та I півріччя 2013 року. Аист Вищого спеціалізованого суду України 3 розгляду цивільних та кримінальних справ вих. № 9-1553/0/4-13 від 03.10.2013. 